\title{
ANALISIS PENGKONSUMSIAN BAHAN BAKAR SISTEM SFI (SEQUENTIAL MULTI PORT FUEL INJECTION) PADA MESIN TIGA SILINDER $1000 \mathrm{CC}$
}

\author{
$\mathrm{AMIR}^{1)} \&$ ALI ROSYIDIN ${ }^{2)}$ \\ Program Studi Teknik Mesin, Fakultas Teknik \\ Universitas Muhammadiyah Tangerang \\ Jl. Perintis Kemerdekaan I/33, Cikokol, Kota Tangerang
}

\begin{abstract}
ABSTRAK
Motor bakar merupakan salah satu mesin kalor yang banyak digunakan sebagai alat penggerak mula. Kemajuan teknologi menjadikan tingkat kebutuhan penggunaan motor bakar semakin meningkat, tetapi berbanding terbalik dengan adanya persediaan bahan bakar daripada motor bakar tersebut. Sistem injeksi dirancang untuk mendapatkan nilai yang mendekati ideal pada kondisi mesin. Bahan bakar diinjeksikan dan dalam jumlah yang sudah tepat, sesuai dengan jumlah udara yang masuk ke dalam intake manifold. Semakin lama waktu pemakain suatu mesin, maka akan semakin menurun kemampuan mesin tersebut, dan akan semakin banyak bahan bakar yang hatus dikomsumsi untuk menghasilkan daya yang besar untuk mengatasi diperlukan Inovasi teknologi menggunakan SFI (Sequential multi port Fuel Injection) merujuk kepada gambaran performance dari kinerja yang diperhatikan kebutuhan penggunaan mesin tersebut, diperlukan perawatan secara berkala dan untuk menghemat pengkomsumsian bahan bakar. SFI (Sequential multi port Fuel Injection) Engine menyediakan kira-kira $10 \%$ tenaga putaran yang lebih besar setiap kali melakukan percepatan.
\end{abstract}

Kata Kunci: Motor Bakar, Fuel Injection, Performance.

\section{LATAR BELAKANG}

Industri otomotif Indonesia memasuki babak baru dalam teknologi motor dan pembuangan, secara resmi pemerintah memberlakukan Keputusan Menteri Lingkungan Hidup Nomor 141/2003 tentang Standar Emisi Euro 2. Peraturan ini berlaku untuk kendaraan produksi terbaru atau yang sedang diproduksi, para Agen Tunggal Pemegang Merek (ATPM) yang beroperasi di Indonesia, menyatakan kesiapan untuk memproduksi kendaraan yang berteknologi ramah lingkungan. Menyiapkan teknologi yang mampu menghasilkan emisi gas buang sesuai standar Euro 2 , menghadirkan sebuah kendaraan yang memiliki nilai lebih bagi lingkungan hidup.

Merancang dan membangun suatu engine kendaraan yang lebih efisien melalui inovasi yang mampu memberikan injection bahan bakar dan udara campuran. Karakter ini memiliki potensi yang besar untuk mengoptimalkan pemasukan bahan bakar, dalam menghasilkan pembakaran yang lebih baik pada pemakaian bahan bakar yang lebih hemat. Merupakan alasan yang memicu dalam usaha menarik perhatian konsumen, untuk mengeluarkan produk yang memiliki keunggulan lebih dari produk sebelumnya. Harapan perancang, kendaraannya menjadi pilihan utama konsumen sebagai otomobil yang memiliki teknologi terbaru dikelasnya.

Pengembangan yang dilakukan terjadi dengan sangat cepat melalui penemuan metode untuk memasukkan bahan bakar tanpa menggunakan karburator. Pemasukan bahan bakar secara efektif dilakukan melalui injector, yang mampu mereduksi kekurangankekurangan pada kinerja engine motor Otto yang telah ada. Electronic fuel Injection Engine merupakan suatu sistem yang memungkinkan, kendali yang tepat terhadap campuran bahan bakar dan udara untuk 
waktu pengapian yang spesifik. Alat untuk sistem ini dipergunakan, bertujuan untuk menghemat pemakaian bahan bakar, tanpa mengganggu daya yang dihasilkan disebut dengan sistem injeksi.

\section{Tujuan Penulisan}

Sistem SFI (Sequential multi port Fuel Injection) adalah sistem pada mesin yang menggunakan sistem elektronik untuk mengatur pengkomsumsian bahan bakar. Tujuan utama sistem SFI adalah meningkatkan prestasi mesin dan mengefesiensikan pengkonsumsian bahan bakar.

Dalam penelitian ini, di coba untuk menganalisis sistem injeksi sistem SFI ( $S e$ quential multi port Fuel Injection) pada mesin tiga silinder $1000 \mathrm{cc}$.

\section{Batasan Masalah}

Dalam penelitian, masalah yang akan dianalisa adalah sistem injeksi SFI Mesin yang akan dianalisa dalam tugas tesis adalah sistem SFI(Sequential multi port Fuel Injection). Batasan penganalisaan meliputi:

1. Bahan bakar yang dikomsumsi dengan spesifikasi minimal Research Octan Number (RON) 92

2. Pembahasan hanya berdasarkan konversi energi

3. Penganalisan dilakukan pada produk Toyota Agya dengan mobil sistem SFI

4. Penganalisaan ini berdasarkan data-data yang diperoleh dari PT. Toyota Astra Motor

Dengan memperhatikan bentuk dan metodologi yang sudah ada, diharapkan analisis dapat dibuat dalam bentuk sederhana tanpa mengabaikan unjuk kerja mesin tersebut.

\section{Perumusan Masalah}

Adapun perumusan masalah yang akan menjadi objek pada penelitian ini adalah "Bagaimana gambaran teoritis tentang analisis kinerja atas SFI(Sequential multi port Fuel Injection) pada mesin tiga silinder $1000 \mathrm{cc}$.

\section{Metode Penelitian}

Metode penelitian yang dipergunakan adalah metode deskriptip analitik, yaitu suatu metode yang digunakan untuk memecahkan permasalahan yang sedang dihadapi pada situasi sekarang. Penelitian deskriptip merupan penelitian yang dimaksudkan untuk me- ngumpulkan informasi mengenai status gejala yang ada, yaitu keadaan gejala menurut apa adanya saat penelitian dilakukan.

\section{TINJAUN PUSTAKA \\ 1. Teknologi Otomotif}

Pertumbuhan kendaraan yang tak terkendali menyebabkan meningkatnya permintaan energi oleh konsumen. Teknologi Otomotif menjadi semakin penting untuk dikuasai dan dikembangkan. Sumber daya manusia yang mampu mengusai dan mengembangkan teknologi Otomotif makin dibutuhkan. Maka dengan perkembangan ilmu dan teknologi dan meningkatkan baik kualitas maupun kuantitas dari produk Teknologi.

Teknik otomotif adalah salah satu cabang ilmu teknik mesin yang mempelajari tentang bagaimana merancang, membuat dan mengembangkan alat-alat transportasi darat yang menggunakan mesin, terutama sepeda motor, mobil, bis dan truk. Teknik otomotif menggabungkan elemen-elemen pengetahuan mekanika, listrik, elektronik, keselamatan dan lingkungan serta matematika, fisika, kimia, biologi dan manajemen.

Cabang-cabang dari teknik otomotif meliputi:

- Perencanaan (product atau design);

- Pengembangan (development);

- Produksi (manufacturing); dan

- Perawatan (maintenance).

\section{Kajian Umum Motor Bakar Torak}

Motor pembakaran dalam pada umumnya dikenal dengan nama motor bakar torak, proses pembakaran berlangsung didalam motor bakar sendiri. Sehingga gas pembakaran yang terjadi, sekaligus berfungsi sebagai fluida kerja. Motor bakar torak mempergunakan beberapa silinder, didalamnya terdapat torak yang bergerak bolak-balik. Pembakaran bahan bakar terjadi didalam silinder, bolak-balik torak menyebabkan gerak rotasi pada poros engkol.

Campuran bahan bakar udara di dalam silinder motor Otto harus sesuai dengan syarat busi di atas, yaitu jangan terbakar sendiri. Ketika busi mengeluarkan api listrik yaitu pada saat beberapa derajat engkol sebelum torak mencapai TMA, campuran bahan bakar udara sekitar itulah yang mula-mula terbakar. Selanjutnya nyala api merambat ke segala arah dengan kecepatan yang sangat tinggi, menya- 
lakan campuran yang dilaluinya sehingga tekanan gas didalam silinder naik, sesuai dengan jumlah bahan bakar yang terbakar.

Mekanisme penyaluran bahan bakar motor konvensional, lazim memakai sistem percampuran bahan bakar pada karburator. Kondisi tersebut terjadi pula dalam engine Multi Point Injection, bahan bakar dikabutkan pada masing-masing ruang pemasukan Intake $M a$ nifold. Menunggu katup masuk terbuka, disaat yang sama butiran bahan bakar yang belum terkabutkan, menguap oleh radiasi panas dari engine. Keadaan tersebut diatas menyebabkan MPI engine, memiliki batasan respon pemasukan bahan bakar dan kontak untuk pembakaran. Hal itu disebabkan percampuran bahan bakar dan udara, terjadi sebelum masuk ke dalam silinder.

\section{Teknologi SFI (Sequential multi port Fuel Injection)}

Sistem SFI tipe-D, mengkalkulasi volume udara masuk berdasarkan signal tekanan intake manifold yang diterimadari vacuum sensor dan engine speed. Sistem injeksi Independent, yang mana bahan bakar diinjeksikan sekali ke setiap cylinder dalam dua putaran crankshaft.

Dua format injeksi bahan bakar:

1. Synchronous injection, terjadi dengan waktu yang sama sesuai dengan durasi injeksi dasar dan koreksi ambahan berdasarkan sinyal yang diberikan oleh sensor.

2. Non Synchronous injection, terjadi pada saat permintaan injeksi berdasarkan sinyal yang diberikan oleh sensor terdeteksi, tidak tergantung dari posisi crankshaft.

Pengurutan penembakan injeksi ke mesin sangatlah akurat dan selalu memenuhi kebutuhan regulator port fuel injection. Bagaimanapun juga, pengurutan tersebut sangatlah penting dan bernilai tinggi untuk bentuk dan pembuatan. Dalam sistem ini perhitungan dan penekanan injektor dengan sendirinya, kebanyakan seperti busi yang urutan operasi penembakannya ke mesin. Sistem ini sering disebut Sequential Fuel Injection atau SFI. Setiap silinder menerima satu pengisian tiap 2 poros engkol bergerak, sebelum katup intake terbuka. Ini berarti bahwa campuran tidak pernah statis dalam intake manifold dan penyesuaian campuran hampir dapat dilaku- kan seketika antara penembakan injektor yang pertama dengan penembakan yang berikutnya. Camshaft posistion sensor (CMP) atau pengisian direferensikan ke distribusi khusus untuk menginformasikan ke sensor kecepatan ketika silinder no. 1 pada langkah kompresi, jika sensor gagal atau pengisian terganggu, beberapa sistem injeksi ditutup sementara yang kembali berfungsi secara bersamaan.

Keuntungan utama dalam penggunaan sistem injeksi adalah sangat sederhananya throttle body yang hanya berisi bahan bakar pada intake manifold dan udara pada mesin, bukan terdiri atas campuran udara dan bahan bakar. Ini memungkinkan desain mesin untuk mengacu pada desain lama. Penyesuaian pada intake manifold sebagai bagian yang tergelincir yang membantu mesin untuk menghasilkan torsi pada kecepatan rendah.

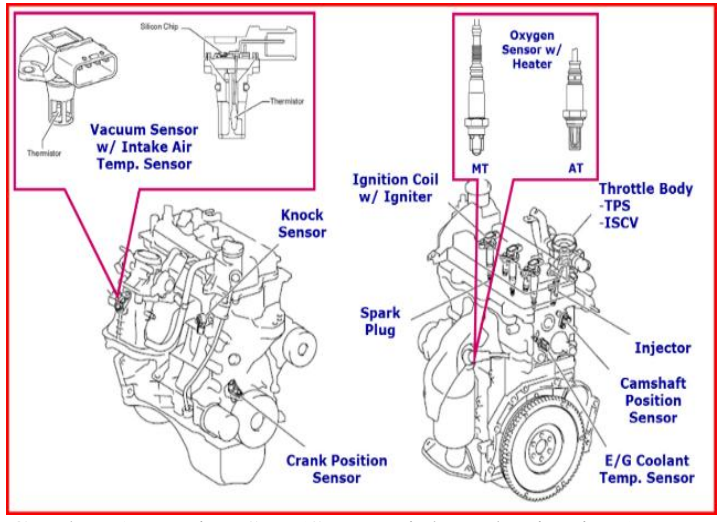

Gambar 1. Engine SFI (Sequential Fuel Injection ).

\section{Sistem Kontrol Mesin}

1) Sistem kontrol mesin menggunakan ECU untuk semua pengontrolan injek-si bahan bakar;

2) Electronic spark advance, idle speed, dll.;

3) Transmission control computer jadi satu dengan ECU \& berkomunikasi di dalam $\mathrm{ECU}(\mathrm{A} / \mathrm{T})$;

4) Dilengkapi dengan fungsi fail safe;

5) Memastikan performa kemudi yang minimum dan melindungi sistem;

6) Menggunakan sistem kontrol knock tipe non-resonance;

7) Memberikan kontrol output yang sesuai berdasarlan angka oktan bahan bakar;

8) Menggunakan injeksi yang berurutan;

9) Kontrol rasio udara-bahan bakar yang sesuai; dan

10) Efisiensi bahan bakar lebih baik, emisi gas buang berkurang. 


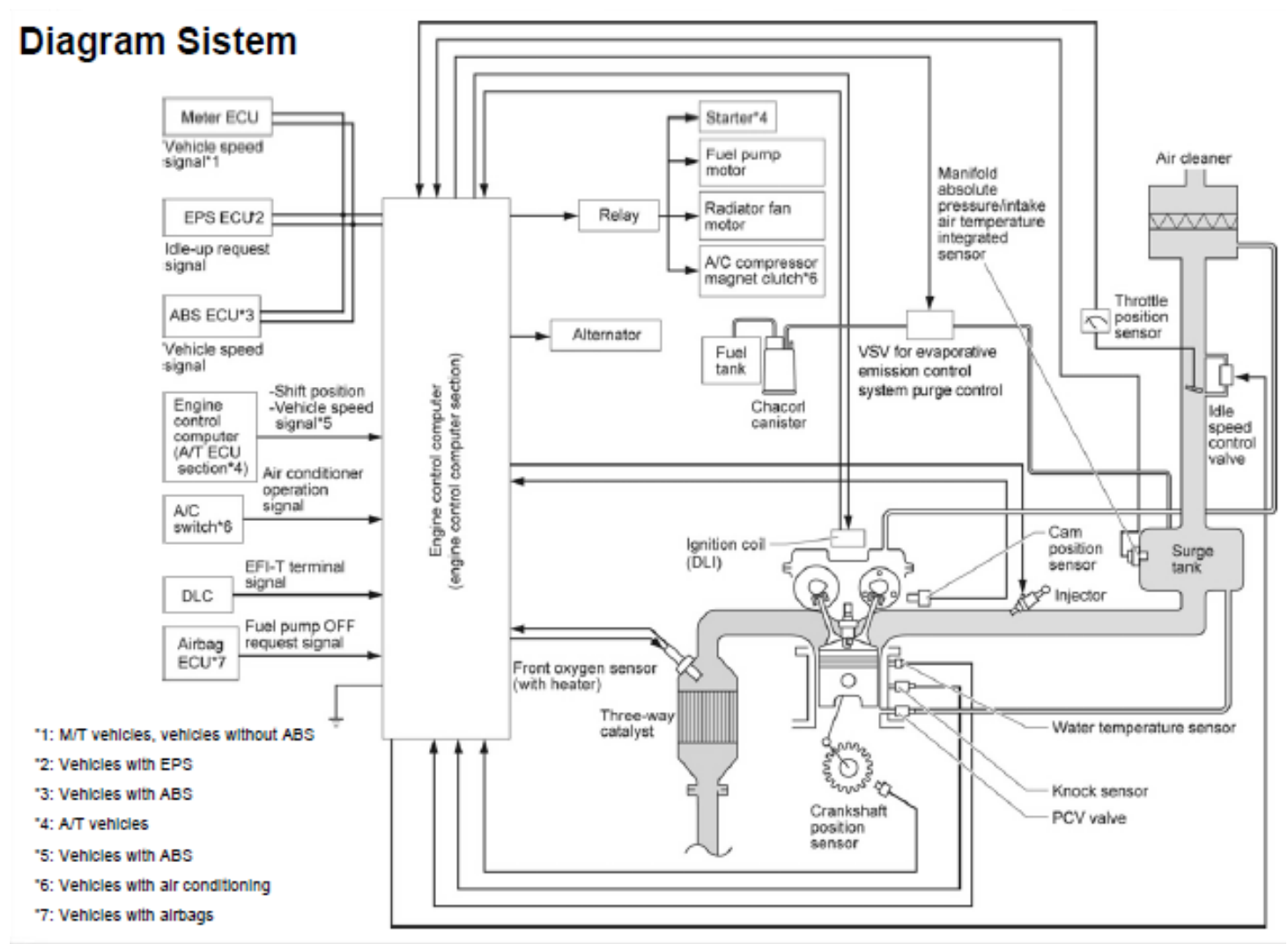

Gambar 2. Diagram Sistem Kontrol Mesin.

\section{Perhitungan Prestasi Mesin}

Mesin Fuel Injection pada dasarnya adalah motor bakar yang menghasilkan daya, dimana yang berguna daya poros, karena poros itulah yang menggerakan beban. Daya poros itu sendiri dibangkitkan oleh daya indikator yang merupakan daya gas pembakaran yang menggerakkan torak.

\section{Siklus Mesin}

Dalam perencanaan ini ditentukan bahwa yang digunakan atau direncanakan adalah siklus dengan volume konstan atau lebih dikenal dengan siklus otto dalam perhitungan selanjutnya diadakan idealisasi sebagai berikut:

1) Proses kompresi berlangsung secara adiabatic;

2) Proses pembakaran berlangsung setelah proses kompesi, dimana sebagaian panas diberikan kepada media kerja dengan kondisi volume konstan $(\mathrm{v}=\mathrm{c})$;

3) Proses ekspansi berlansung secara adiabatic dan dianggap terus berlangsung sampai tekanannya sama dengan tekanan atmosfer;

4) Tekanan didalam silinder selama langkah isap dianggap konstan; dan
5) Fluida kerja dianggap gas ideal.

Adapun bagan diagram siklus dengan volume konstan atau siklus otto dapat dilihat sebagai berikut:
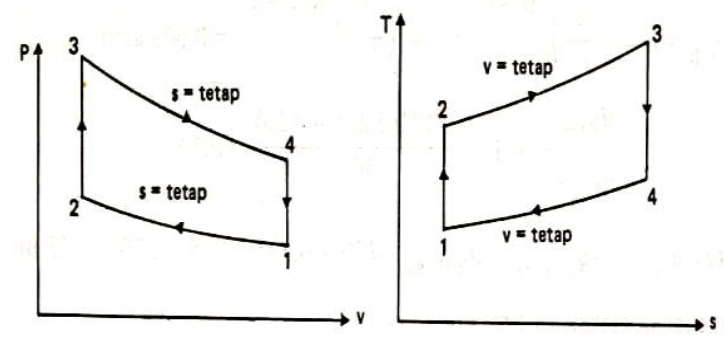

Gambar 3. Diagram P-V dan T-S siklus otto. (Cengel \& Boles, 1994: 451).

Sistem ini dianggap siklus, artinya bahwa siklus ini berlangsung dengan fluida kerja yang sama, yaitu gas (bahan bakar) yang berada didalam silinder pada saat dimasukkan dapat dikeluarkan dri dalam silinder pada saat langkah buang, dan pada saat langkah isap selanjutnya akan masuk pula fluiida kerja dengan jumlah yang sama.

Kerja yang dilakukan oleh udara dalam langkah isap kedalam silinder adalah sama dengan kerja yang dilakukan oleh torak pada 
udara dalam langkah buang. Dalam menganalisa standart siklus otto, pada umumnya langkah-langkah diatas dapat diabaikan, sehingga proses menjadi:

$(1-2)$ : langkah kompresi pada $(\mathrm{s}-\mathrm{c})$

$(2-3)$ : proses pembakaran pada $(\mathrm{v}=\mathrm{c})$

$(3-4)$ : proses ekspansi pada $(\mathrm{s}-\mathrm{c})$

$(4-1)$ : proses pembuangan gas sisa pada $(\mathrm{v}-$ c)

\section{METODOLOGI PENELITIAN}

\section{Spesifikasi Data}
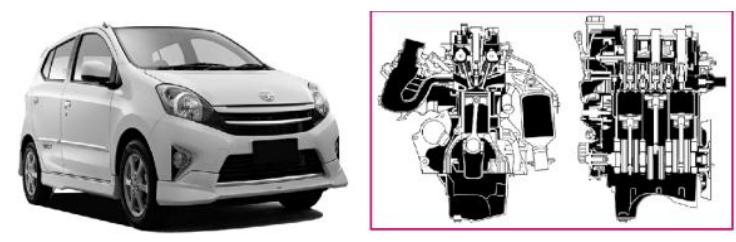

Gambar 4. Mobil 1000cc

Tabel 1. Spesifikasi Mobil 1000 CC

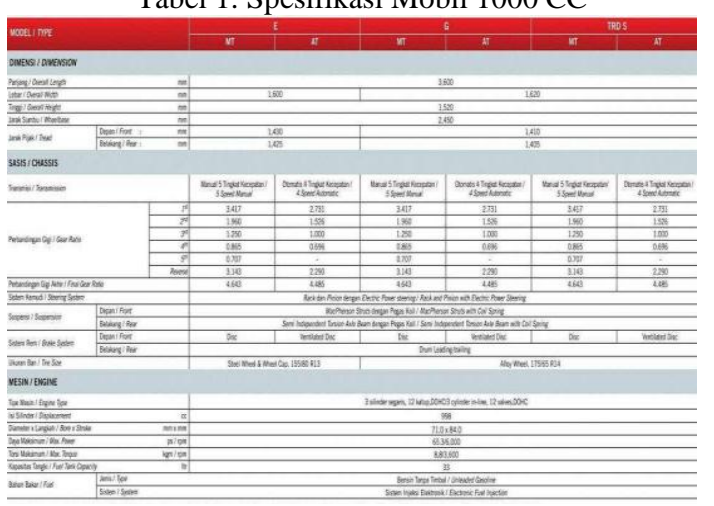

Spesifikasi

Tabel 1. Spesifikasi engine $1000 \mathrm{cc}$

\begin{tabular}{|c|c|c|}
\hline \multicolumn{2}{|r|}{ Data } & SFI Engine $1000 \mathrm{CC}$ \\
\hline \multicolumn{2}{|c|}{ Total Displacement $\mathrm{dm}^{3}$} & 998 \\
\hline \multicolumn{2}{|c|}{ Cylinder Bore $\mathrm{x}$ Stroke $\mathrm{mm}$} & $71 \times 84$ \\
\hline \multicolumn{2}{|c|}{ Combustion Chamber Shape } & Pent Roof \\
\hline \multicolumn{2}{|c|}{ Compression Ratio } & 10 \\
\hline \multicolumn{2}{|l|}{ Valve Mechanism } & $\begin{array}{l}12 \text { Valve DOHC, } \\
\text { Chain Drive }\end{array}$ \\
\hline \multicolumn{2}{|l|}{ Fuel Used } & Ron 90 or Higher \\
\hline \multicolumn{2}{|c|}{ Maximum Output k.W/rpm } & $65 / 6000$ \\
\hline \multicolumn{2}{|c|}{ Maximum Torque N.m/rpm } & $87 / 3600$ \\
\hline \multicolumn{2}{|c|}{ Fuel System } & $\begin{array}{l}\text { SFI (Sequential multi } \\
\text { port Fuel Injection) }\end{array}$ \\
\hline \multirow[t]{2}{*}{ Ignition System } & $\begin{array}{l}\text { Power Distribution } \\
\text { Method }\end{array}$ & DIS \\
\hline & $\begin{array}{l}\text { Ignition Timing } \\
\text { Control }\end{array}$ & $\begin{array}{l}\text { (3 Ignition Coil / } 3 \\
\text { Silinder) }\end{array}$ \\
\hline \multicolumn{2}{|l|}{ Injector } & Tipe 4-Lubang \\
\hline \multicolumn{2}{|l|}{ Idle Control } & ISCV \\
\hline \multicolumn{2}{|l|}{ Lash Adjuster } & Valve lifter tanpa shim \\
\hline \multirow{2}{*}{$\begin{array}{l}\text { Engine Oil API } \\
\text { SLhigher } \mathrm{dm} 3\end{array}$} & Full Capacity & 2.6 \\
\hline & Oil Filter & 2.7 \\
\hline
\end{tabular}

\section{Tempat dan Waktu Penelitian}

Penelitian ini dilakukan di Lab UPT Otomotif, kampus Politeknik Manufaktur Astra.
Waktu penelitian pada tahun 2019.

\section{Alat dan Instrumen Penelitian}

Alat yang dipakai yaitu mobil Jenis Toyota Agya SFI $1000 \mathrm{cc}$, dan alat Dyno test. Instrumen penelitian antara lain: Tachometer dan Speedometer.

\section{Pengamatan/Observasi / pengujian}

Untuk memperoleh data-data pengujian dilakukan dengan cara pengujian secara langsung dan juga dapat diperoleh data daya output pada setiap putaran dengan metode interpolasi.

Diagram Alir Penelitian

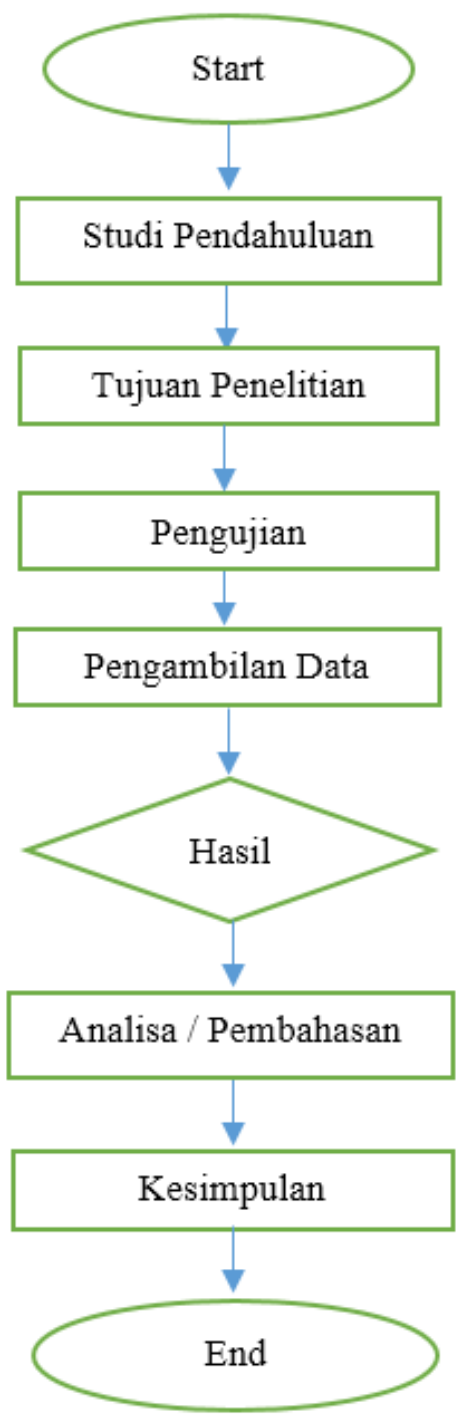

Gambar 5. Diagram Alir Penelitian 


\section{Hasil Pengujian}

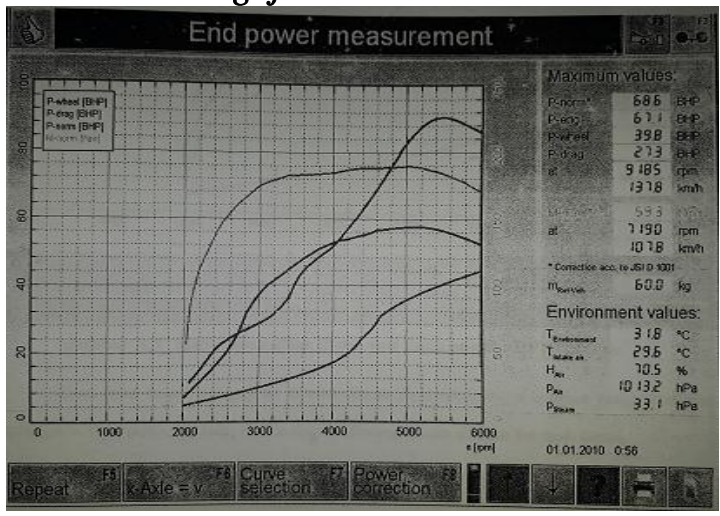

Gambar 6. Hasil pengujian Dyno test pada engine 1000 $c c$.

Dari data diatas pengujian atas dapat diperoleh daya output, maka disimpulkan dalam bentuk tabel.

Tabel 2. Daya output tiap tingkat putaran.

\begin{tabular}{|c|c|c|}
\hline \multirow{2}{*}{$\boldsymbol{n}(\boldsymbol{r p m})$} & \multicolumn{2}{|c|}{ Daya output pada SFI Engine } \\
\cline { 2 - 3 } & $\mathbf{N e}(\mathbf{k W})$ & Ne (PS) \\
\hline 2000 & 8 & 10,72 \\
\hline 2500 & 16 & 21,46 \\
\hline 3000 & 23 & 30,84 \\
\hline 3500 & 33 & 44,25 \\
\hline 4000 & 39 & 52,29 \\
\hline 4500 & 45 & 60,35 \\
\hline 5000 & 63 & 84,48 \\
\hline 5500 & 69 & 92,53 \\
\hline 6000 & 65 & 87,17 \\
\hline
\end{tabular}

\section{ANALISIS}

Analisis Perhitungan Performance Engine SFI (Sequential Multi Port Fuel Injection)

\section{Perhitungan Torsi}

Dengan menggunakan metode interpolasi maka didapat Torsi $(\mathrm{T})$ dari daya efektif $(\mathrm{Ne})$ untuk tiap putaran tertentu dengan melihat data kurva performance engine diatas, yang dicari dengan persamaan:

$$
\begin{aligned}
& N e=\frac{T \cdot n}{716,2} \quad(\mathrm{PS}) \\
& T=\frac{N e \cdot 716,2}{n} \quad(\mathrm{~m} \cdot \mathrm{kg})
\end{aligned}
$$

Tabel 3. Perhitungan torsi dan daya efektif pada tingkat putaran tertentu.

\begin{tabular}{|c|c|c|}
\hline $\mathbf{n}(\mathbf{r p m})$ & $\begin{array}{c}\text { Daya output } \\
\text { pada SFI } \\
\text { Engine Ne } \\
\text { (PS) }\end{array}$ & $\begin{array}{c}\text { Torsi pada SFI } \\
\text { Engine T (m.kg) }\end{array}$ \\
\hline 2000 & 10,72 & 3,8388 \\
\hline 2500 & 21,46 & 6,1479 \\
\hline 3000 & 30,84 & 7,3625 \\
\hline 3500 & 44,25 & 9,0548 \\
\hline 4000 & 52,29 & 9,3625 \\
\hline 4500 & 60,35 & 9,6050 \\
\hline 5000 & 84,48 & 12,1009 \\
\hline 5500 & 92,53 & 12,0491 \\
\hline 6000 & 87,17 & 10,4052 \\
\hline
\end{tabular}

\section{Perhitungan Tekanan Efektif Rata-Rata Motor (Pe)}

Tekanan Efektif Rata-rata Motor (Pe) terjadi didalam silinder dimana tekanan ini merupakan tekanan yang dapat mendorong torak sepanjang langkahnya untuk mendapatkan usaha per-siklus. Tekanan efektif motor dapat diperoleh dengan menggunakan rumus:

$\mathrm{Pe}=\frac{T \times 2 \pi \times 100}{V_{L} \times Z x a}\left(K g / \mathrm{cm}^{2}\right)($ Wiranto A, 1988: 33)

Dimana:

$\mathrm{Pe}=$ Tekanan Efektif rata-rata motor $\left(\mathrm{Kg} / \mathrm{cm}^{2}\right)$

$\mathrm{T}=\operatorname{Momen} \operatorname{putar}(\mathrm{Kg} . \mathrm{cm})$

$\mathrm{V}_{\mathrm{L}}=$ Volume Langkah $\left(\mathrm{cm}^{3}\right)$

$\mathrm{Z}=$ Jumlah Silinder

$\mathrm{n} \quad=$ Putaran motor (rpm)

$\mathrm{a}=$ Siklus perputaran bernilai 0,5 untuk motor 4 langkah

Maka tekanan efektif rata-rata motor untuk tiap tingkat putaran tertentu adalah sebagai berikut: 
Tabel 4. Perhitungan tekanan efektif rata-rata motor

\begin{tabular}{|c|c|c|}
\hline $\mathbf{n}(\mathbf{r p m})$ & $\begin{array}{c}\text { Torsi pada SFI } \\
\text { Engine } \\
\text { T (m.kg) }\end{array}$ & $\begin{array}{c}\text { Pe pada SFI } \\
\text { engine } \\
\left(\mathrm{Kg} / \mathrm{cm}^{2}\right)\end{array}$ \\
\hline 2000 & 3,8388 & 4,8351 \\
\hline 2500 & 6,1479 & 7,7433 \\
\hline 3000 & 7,3625 & 9,2732 \\
\hline 3500 & 9,0548 & 11,4046 \\
\hline 4000 & 9,3625 & 11,7922 \\
\hline 4500 & 9,6050 & 12,0977 \\
\hline 5000 & 12,1009 & 15,2412 \\
\hline 5500 & 12,0491 & 15,1760 \\
\hline 6000 & 10,4052 & 14,8906 \\
\hline
\end{tabular}

\section{Perhitungan Penggunaan Bahan Bakar}

Untuk mencari perhitungan pemakaian bahan bakar (Gf) dapat menggunakan persamaan:

$\mathrm{Gf}=\frac{\mathrm{Ne} \cdot 632}{\eta_{\mathrm{th}} \cdot \mathrm{Qc}} \quad(\mathrm{kg} / \mathrm{jam})($ Khovakh, 1976: 73)

$\eta_{\text {th }}=\frac{N e}{G f x N p b} \times 632 \times 100 \%(100 \%)$ (Wiranto A, 1988: 33)

$\eta_{\mathrm{th}}=\frac{\mathrm{Q}_{1}-\mathrm{Q}_{2}}{\mathrm{Q}_{1}}$ atau $\eta_{\mathrm{th}}=1-\left(\frac{1}{\mathrm{r}}\right)^{\mathrm{k}-1}$

(Wiranto

A,

1995:26)

Dimana:

$\mathrm{Ne}$ = Daya efektif, (PS)

Qc = Nilai kalor bawah bahan bakar, menurut (SP. Sein, 1980: 168) besarnya $10580 \mathrm{kkal} / \mathrm{kg}$,

$\mathrm{G}_{\mathrm{f}}=$ Pemakaian bahan bakar, (kg/jam)

$\mathrm{r}=$ Perbandingan kompresi, spesifikasi $(\mathrm{SFI}=10)$

$\eta_{\text {th }}=$ Efisiensi Thermis (\%)

$\mathrm{Npb}=$ Nilai kalor bahan bakar (kkal/jam)

Nilai kalor bahan bakar (kkal/jam)

premium $=10580 \mathrm{kkal} / \mathrm{jam}$

(Wiranto A, 1988: 28)

untuk SFI

$\eta$ th $=1-\left(\frac{1}{10}\right)^{0.302}=0,501$

Setelah nilai Gf diketahui,maka nilai pemakaian bahan bakar spesifik dapat dicari dengan menggunakan rumus:

$\mathrm{Be}=\frac{G f}{N e} \quad(\mathrm{~kg} / \mathrm{PSjam})($ Wiranto A, 1994:29)
Maka jumlah bahan bakar dan nilai bahan bakar spesifik yang dapat masuk ke dalam silinder pada tiap tingkat putaran tertentu adalah sebagai berikut:

Tabel 5. Perhitungan pemakaian jumlah bahan bakar dan nilai pemakaian bahan bakar spesifik yang digunakan pada tiap tingkat putaran tertentu.

\begin{tabular}{|c|c|c|c|c|}
\hline N (rpm) & $\begin{array}{c}\text { Daya output } \\
\text { pada SFI } \\
\text { Engine } \\
\text { Ne (PS) }\end{array}$ & $\begin{array}{c}\boldsymbol{\eta}_{\text {th }} \text { (\%) } \\
\text { untuk SFI }\end{array}$ & $\begin{array}{c}\text { Gf (kg/jam) } \\
\text { SFI Engine }\end{array}$ & $\begin{array}{c}\text { Be (kg/PSjam) } \\
\text { SFI Engine }\end{array}$ \\
\hline 2000 & 10,72 & 50,1 & 2,3846 & 0,2224 \\
\hline 2500 & 21,46 & 50,1 & 2,9808 & 0,1389 \\
\hline 3000 & 30,84 & 50,1 & 3,5770 & 0,1160 \\
\hline 3500 & 44,25 & 50,1 & 4,1731 & 0,0943 \\
\hline 4000 & 52,29 & 50,1 & 4,7693 & 0,0912 \\
\hline 4500 & 60,35 & 50,1 & 5,3655 & 0,0889 \\
\hline 5000 & 84,48 & 50,1 & 5,9616 & 0,0706 \\
\hline 5500 & 92,54 & 50,1 & 6,5578 & 0,0709 \\
\hline 6000 & 87,17 & 50,1 & 7,1539 & 0,0821 \\
\hline
\end{tabular}

\section{Perhitungan Daya Indikator (Ni)}

Daya indikator $(\mathrm{Ni})$ diperoleh dengan rumus:

$\mathrm{Ni}=\mathrm{Ne} / \eta_{\text {Mek }}(\mathrm{PS})$ (Wiranto A., 1988: 33)

Setelah daya indikator diperoleh, maka nilai permakaian bahan bakar spesifik indikator $(\mathrm{Bi})$ dapat dicari dengan rumus:

$\mathrm{Bi}=\mathrm{Gf} / \mathrm{Ni}$ (kg/Psjam)

$\eta_{\text {Mek }}=$ Efisiensi mekanis motor bensin $0,70-$ $0,85(\%)$ diambil 0,80

Dengan menggunakan persamaan di atas maka dapat dihitung daya indikator dan nilai pemakaian bahan bakar spesifik indikator untuk tiap tingkat putaran sebagai berikut:

Tabel 6. Perhitungan daya indikator untuk tiap tingkat putaran.

\begin{tabular}{|c|c|c|c|c|}
\hline $\mathbf{n}(\mathbf{r p m})$ & $\begin{array}{c}\text { Daya output } \\
\text { SFI Engine } \mathrm{Ne} \\
\text { (PS) }\end{array}$ & $\begin{array}{c}\text { Daya } \\
\text { indikator } \\
\text { pada SFI } \\
\text { Engine } \text { Ni } \\
\text { (PS) }\end{array}$ & $\begin{array}{c}\text { Gf (kg/jam) } \\
\text { SFI Engine }\end{array}$ & $\begin{array}{c}\text { Bi (kg/PSjam) } \\
\text { untuk SFI } \\
\text { Engine }\end{array}$ \\
\hline 2000 & 10,72 & 50,1 & 2,3846 & 0,2224 \\
\hline 2500 & 21,46 & 50,1 & 2,9808 & 0,1389 \\
\hline 3000 & 30,84 & 50,1 & 3,5770 & 0,1160 \\
\hline 3500 & 44,25 & 50,1 & 4,1731 & 0,0943 \\
\hline 4000 & 52,29 & 50,1 & 4,7693 & 0,0912 \\
\hline 4500 & 60,35 & 50,1 & 5,3655 & 0,0889 \\
\hline 5000 & 84,48 & 50,1 & 5,9616 & 0,0706 \\
\hline 5500 & 92,53 & 50,1 & 6,5578 & 0,0709 \\
\hline 6000 & 87,17 & 50,1 & 7,1539 & 0,0821 \\
\hline
\end{tabular}




\section{Perhitungan Efisiensi Volumetris $\left(\eta_{\text {vol }}\right)$}

$\eta_{\mathrm{Vol}}=\frac{B M}{B M^{\prime}} \times 100 \%(100 \%)($ Khovak 1979: 10)

Pada motor 4-langkah perbandingan antara jumlah udara masuk yang sebenarnya terhadap yang ideal dinamai efisiensi volumetrik $\left(\eta_{\mathrm{v}}\right)$ (Wiranto A, 1977:107), yang dapat juga dicari dengan persamaan:

$\eta_{\mathrm{Vol}}=\frac{G a}{G a i}$

Gai $=\mathrm{V}_{\mathrm{L}} \times \gamma_{\mathrm{ai}} \times \mathrm{z} \times \mathrm{n} \times 0,5 \times 60$ (Wiranto A, 1994:106)

$\mathrm{z}=$ jumlah silinder,spesifikasi $=3$

P. $V=$ G. R. T

$P=\frac{G}{V} \times R \times T=\gamma_{a i} \cdot R \cdot T$

$\gamma_{a i}=\frac{P}{R \cdot T}=\frac{10330}{29,3 \times 300}=1,175 \mathrm{~kg} / \mathrm{m}^{3}$

Sehingga Gai pada putaran $5000 \mathrm{rpm}$ dapat diperoleh

$$
\begin{aligned}
\mathrm{Gai}= & \left(332,425 \times 10^{-6}\right) \times 1,175 \times 6 \times 5000 \times 0,5 \times 60 \\
= & 175,76 \mathrm{~kg} / \mathrm{jam}
\end{aligned}
$$

Dengan cara yang sama, maka akan didapat juga Gai untuk tiap tingkat putaran. Setelah Gai didapat maka Ga dari persamaan: $\mathrm{f}=\mathrm{Gf} / \mathrm{Ga}$ (Wiranto A,1977:29)

$\mathrm{f}=$ perbandingan bahan bakar dan udara $=$ 0,0662 (E.F.Robert,1968:193)

Dengan menggunakan persamaan di atas maka diperoleh nilai efisiensi volumetris pada tiap tingkat putaran sebagai berikut:

Tabel 7. Perhitungan efisiensi volumetris untuk tiap tingkat putaran tertentu.

\begin{tabular}{|c|c|c|c|c|}
\hline $\mathbf{n}(\mathbf{r p m})$ & Gai (kg/jam) & $\begin{array}{c}\text { Gf(kg/jam) } \\
\text { SFI Engine }\end{array}$ & $\begin{array}{c}\text { Ga (kg/jam) } \\
\text { SFI Engine }\end{array}$ & $\begin{array}{c}\eta_{\text {vol (\%) }} \\
\text { untuk SFI }\end{array}$ \\
\hline 2000 & 70,3034 & 2,3846 & 36,0218 & 51,2376 \\
\hline 2500 & 87,8793 & 2,9808 & 45,0273 & 51,2376 \\
\hline 3000 & 105,4552 & 3,5770 & 54,0327 & 51,2376 \\
\hline 3500 & 123,0310 & 4,1731 & 63,0382 & 51,2376 \\
\hline 4000 & 140,6069 & 4,7693 & 72,0436 & 51,2376 \\
\hline 4500 & 158,1828 & 5,3655 & 81,0491 & 51,2376 \\
\hline 5000 & 175,7586 & 5,9616 & 90,0546 & 51,2376 \\
\hline 5500 & 193,3345 & 6,5578 & 99,0600 & 51,2376 \\
\hline 6000 & 210,9103 & 7,1539 & 108,0655 & 51,2376 \\
\hline
\end{tabular}

\section{Analisis Proses Thermodinamika}

\begin{tabular}{|c|c|c|}
\hline & Thermodinamika & SFI Engine \\
\hline \multirow[t]{2}{*}{$\mathrm{a}$} & Volume langkah (VL) $\left(\mathrm{m}^{3}\right)$ & $3,32 \times 10^{-4}$ \\
\hline & Volume Sisa $\left(\mathrm{m}^{3}\right)$ & $3,69 \times 10^{-5}$ \\
\hline \multirow[t]{6}{*}{ b } & \multicolumn{2}{|l|}{ Proses $0-1$ (Langkah Hisap) } \\
\hline & - Tekanan pada titik 0 - $1\left(\mathrm{P}_{0}=\mathrm{P}_{1}\right)$ (bar) & 1 \\
\hline & - Temperatur Spesifik pada titik $0-1\left(\mathrm{~T}_{0}=\mathrm{T}_{1}\right)(\mathrm{k})$ & 303 \\
\hline & - Massa campuran bahan dan udara (kg) & $4,25 \times 10^{-4}$ \\
\hline & - Massa udara pembakaran (kg) & $3,78 \times 10^{-4}$ \\
\hline & - Massa bahan bakar & $2,59 \times 10^{-5}$ \\
\hline \multirow[t]{5}{*}{ c } & \multicolumn{2}{|l|}{ Proses 1 -2 (Langkah Kompresi) } \\
\hline & - Volume pada titik $1\left(\mathrm{~V}_{1}\right)\left(\mathrm{m}^{3}\right)$ & $3,69 \times 10^{-4}$ \\
\hline & - Tekanan pada titik $2\left(\mathrm{P}_{2}\right)$ (bar) & 20,044 \\
\hline & - Temperatur Spesifik pada titik $2\left(\mathrm{~T}_{2}\right)(\mathrm{k})$ & 607,35 \\
\hline & - Volume pada titik $2\left(\mathrm{~V}_{2}\right)(\mathrm{m} 3)$ & $3,69 \times 10^{-5}$ \\
\hline \multirow[t]{7}{*}{$\mathrm{d}$} & \multicolumn{2}{|l|}{ Proses $2-3$ ( langkah Pembakaran) } \\
\hline & - Volume pada titik $3\left(\mathrm{~V}_{3}\right)=\left(\mathrm{V}_{2}\right)\left(\mathbf{m}^{3}\right)$ & $3,69 \times 10^{-5}$ \\
\hline & - Berat Molekul gas (m) (kg) & $4,25 \times 10^{-5}$ \\
\hline & - Tekanan pada titik $3\left(\mathrm{P}_{3}\right)$ (bar) & 115,13 \\
\hline & - Temperatur Spesifik pada titik $3\left(\mathrm{~T}_{3}\right)(\mathrm{k})$ & 3488,33 \\
\hline & $\begin{array}{l}\text { - Panas jenis gas pada volume konstan }\left(\mathrm{C}_{\mathrm{w}}\right) \\
(\mathrm{J} / \mathrm{Kg} . \mathrm{K})\end{array}$ & 950,33 \\
\hline & -Kalor yang masuk $\left(\mathrm{Q}_{\text {in }}\right)$ (joule) & 1162,82 \\
\hline \multirow[t]{5}{*}{$\mathrm{e}$} & \multicolumn{2}{|l|}{ Proses 3-4 (Langkah Ekspansi) } \\
\hline & - Volume pada titik $4\left(\mathrm{~V}_{4}\right)=\left(\mathrm{V}_{1}\right)\left(\mathrm{m}^{3}\right)$ & $3,69 \times 10^{-4}$ \\
\hline & - Tekanan pada titik $4\left(\mathrm{P}_{4}\right)($ bar $)$ & 5,743 \\
\hline & - Temperatur Spesifik pada titik $4\left(\mathrm{~T}_{4}\right)(\mathrm{k})$ & 1740,27 \\
\hline & - Kalor yang keluar ( $Q_{\text {out }}$ ) (joule) & 580,09 \\
\hline $\mathrm{f}$ & Efisiensi thermis, $\%\left(\eta_{\text {th }}\right)$ & 50,11 \\
\hline $\mathrm{g}$ & Kerja Thermal (joule) & 582,72 \\
\hline $\mathrm{h}$ & Daya Thermal (watt) & 87,41 \\
\hline $\mathrm{i}$ & Efisiensi Relatif $\left(\eta_{\mathrm{I}}\right)$ (diasumsikan) & 0,95 \\
\hline $\mathrm{i}$ & Efisiensi Mekanis ( $\left.\eta_{m}\right)$ (diasumsikan) & 0,8 \\
\hline $\mathrm{k}$ & Efisiensi Indikator $\left(\eta_{i}\right)$ & 0,47 \\
\hline 1 & Efisiensi Total $\left(\eta_{b}\right)$ & 0,38 \\
\hline $\mathrm{m}$ & Perhitungan Daya Indikator ( $\mathrm{Pi}$ ) (watt) & 83,04 \\
\hline $\mathrm{n}$ & Perhitungan Daya Poros ( $\mathrm{Pp}$ ) (watt) & 66,43 \\
\hline
\end{tabular}

Tabel 8. Perhitungan Thermodinamika.

\section{Analisa Grafik}

Berdasarkan hasil dari pengujian maka dapat diperoleh grafik daya efektif, torsi, tekanan efektif dan pemakaian bahan bakar antara lain:

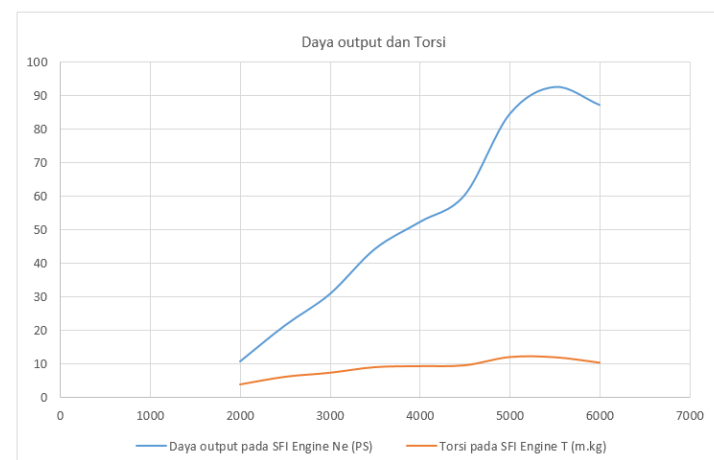

Gambar 7. Daya output dan Torsi pada tiap tingkat putaran. 


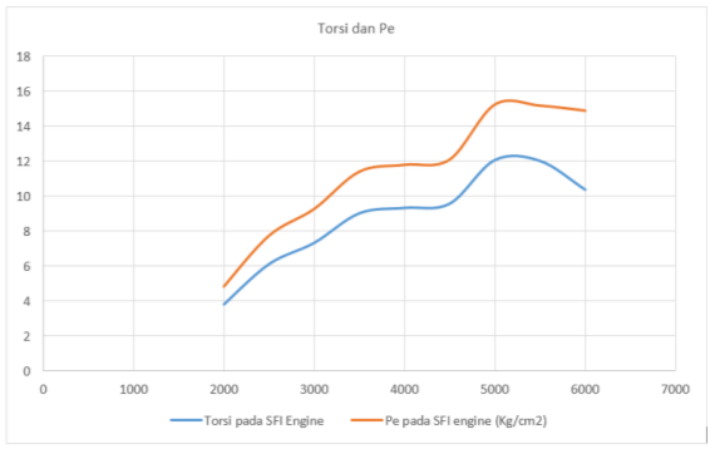

Gambar 8. Tekanan efektif terhadap Torsi pada tiap tingkat putaran.

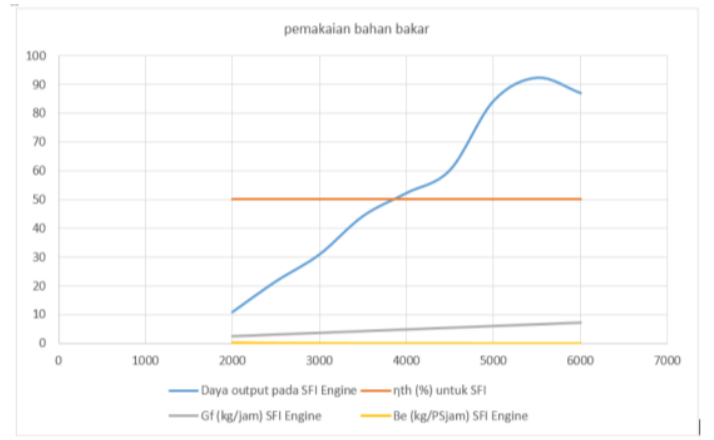

Gambar 7. Pemakaian bahan bakar terhadap daya output dan efisiensi thermis pada tiap tingkat putaran.

\section{PENUTUP}

\section{Kesimpulan}

Dari hasil pengujian mesin sistem SFI (Sequential Multi Port Fuel Injection), diperoleh data-data mengenai kemampuan mesin. Adapun hasil yang diperoleh dapat kita ambil beberapa kesimpulan, di antara sebagai berikut:

a. Untuk mengetahui kemampuan suatu mesin digunakan alat yang dinamakan "Engine Test Performance", dimana alat tersebut terdiri dari berbagai alat-alat lainnya: Dynamometer yang digunakan untuk mengukur momen puntir (torsi) dan daya mesin serta Takometer yang digunakan untuk mengukur kecepatan putar poros engkol. Alat ini memudahkan suatu perusahaan khususnya pada bidang otomotif untuk melakukan pengujian mesin.

b. Pada prinsipnya proses dari mesin SFI sama halnya proses mesin yang menggunakan karburator, tetapi mesin SFI lebih baik dibandingkan dengan mesin karburator, khususnya dalam pengkonsumsian bahan bakar yang di injeksikan menghasilkan butiran-butiran halus sehingga lebih cepat bereaksi dengan udara. c. Mesin SFI lebih efisiensi dimana bahan bakar yang dikonsumsi dapat diatur sesuai dengan kebutuhan kerja mesin tersebut. sehingga mengurangi kemungkinan terjadinya campuran kaya didalam silinder.

d. Akan tetapi berdasarkan hasil pengujian mesin SFI khususnya pada mesin tiga silinder $1000 \mathrm{cc}$ ini juga memiliki beberapa kelemahan yang dapat dicegah yaitu:

1) Komponen dari mesin tersebut sangat sensitif, tidak boleh sembarang dilakukan perbaikan, karena menggunakan alat-alat khusus, dalam hal ini perawatan harus rutin dilakukan pada bengkel-bengkel yang resmi.

2) Semakin lama waktu pemakaian mesi tersebut, maka akan semakin menurun kemampuan mesin tersebut, dan akan semakin banyak bahan bakar yang harus dikonsumsi untuk menghasilkan daya yang besar.

3) Bahan bakar yang di konsumsi oleh mesin SFI ini, tidak boleh sembarang. karena akan cepat merusak komponen-komponen dari mesin SFI tersebut.

4) Hasil dari pengujian merupakan data-data yang dapat dipastikan kebenarannya, adapun hasilnya tidak luput kemungkinan dari kesalahankesalahan baik dari operator, alat penguji dan kondisi mesin tersebut.

\section{Saran}

Untuk menghemat pemakaian bahan bakar pada mesin SFI tiga silinder $1000 \mathrm{cc}$, haruslah diperhatikan dahulu kebutuhannya. Seperti pemakaian kendaraan didalam kota dan pemakaian kendaraan diluar kota.

Khusus didalam kota, sulit kita prediksikan, kemacetan lalu lintas bisa terjadi sewaktuwaktu. Karena kendaraan tidak bergerak (statis) sehingga putaran meisn yang dihasilkan tidak dapat dimanfaatkan untuk menggerakan roda. Sehingga bahan bakar akan menjadi terbuang sia-sia. Solusinya haruslah dibuat suatu sistem penggerak tanpa menggunakan bahan bakar tersebut khusus pada saat kemacetan lalulintas. 


\section{DAFTAR PUSTAKA}

Arismunandar, W. (2002)), Penggerak Mula Motor Bakar Torak, Bandung: Penerbit ITB.

Heywood Jhon B (1998), Internal Combustion Engine Fundamentals, McGraw Hill Book Company, New York.

I Nyoman Sutantra Bambang Sampurno (2010), Teknologi Otomotif. Surabaya: Penerbit GunaWidya.

James D. Halderman, Jim Linder (2009). Automotive Fuel And Emissions Control
System (second edition): Prentice Hall Upper Saddle, New Jersey Columbus, Ohio.

Khovakh (1976). Motor Vehicles Engine. Moscow. Mr.Publiser.

Toyota Astra International. (2013). Modul Training Product Knowlegde "Toyota Agya". Jakarta

Toyota Astra International. (1995). “New Step I (Training Manual)” Jakarta. PT. Astra International - Toyota. 